\title{
Estimation of Fetal Weight during Labor: Still a Challenge
}

\section{Estimativa do peso fetal intraparto: ainda um desafio}

\author{
Joana Goulão Barros ${ }^{1}$ Inês Reis ${ }^{1} \quad$ Isabel Pereira ${ }^{1} \quad$ Nuno Clode $^{1} \quad$ Luís M. Graça $^{1}$ \\ ${ }^{1}$ Departamento de Obstetrícia, Ginecologia e Medicina Materno-Fetal \\ do Hospital Universitário de Santa Maria, Centro Hospitalar Lisboa \\ Norte, Lisboa, Portugal \\ Address for correspondence Joana Goulão Barros, MD, CHLN - \\ Hospital Universitário de Santa Maria, Av. Prof. Egas Moniz, 1649-035 \\ Lisboa, Portugal (e-mail: joanagmb@gmail.com).
}

Rev Bras Ginec Obst 2016;38:4-8.

\begin{abstract}
Keywords

- estimation fetal weight

- labor

- macrossomia

- low birth weight

\section{Resumo}

Objective To evaluate the accuracy of fetal weight prediction by ultrasonography labor employing a formula including the linear measurements of femur length (FL) and mid-thigh soft-tissue thickness (STT).

Methods We conducted a prospective study involving singleton uncomplicated term pregnancies within 48 hours of delivery. Only pregnancies with a cephalic fetus admitted in the labor ward for elective cesarean section, induction of labor or spontaneous labor were included. We excluded all non-Caucasian women, the ones previously diagnosed with gestational diabetes and the ones with evidence of ruptured membranes. Fetal weight estimates were calculated using a previously proposed formula [estimated fetal weight $=-1687.47+(54.1 \times \mathrm{FL})+(76.68 \times \mathrm{STT})$. The relationship between actual birth weight and estimated fetal weight was analyzed using Pearson's correlation. The formula's performance was assessed by calculating the signed and absolute errors. Mean weight difference and signed percentage error were calculated for birth weight divided into three subgroups: $<3000 \mathrm{~g} ; 3000-4000 \mathrm{~g}$; and $>4000 \mathrm{~g}$.

Results We included for analysis 145 cases and found a significant, yet low, linear relationship between birth weight and estimated fetal weight $\left(p<0.001 ; R^{2}=0.197\right)$ with an absolute mean error of $10.6 \%$. The lowest mean percentage error $(0.3 \%)$ corresponded to the subgroup with birth weight between $3000 \mathrm{~g}$ and $4000 \mathrm{~g}$.

Conclusions This study demonstrates a poor correlation between actual birth weight and the estimated fetal weight using a formula based on femur length and mid-thigh soft-tissue thickness, both linear parameters. Although avoidance of circumferential ultrasound measurements might prove to be beneficial, it is still yet to be found a fetal estimation formula that can be both accurate and simple to perform.

Objetivo Avaliar a precisão da determinação ultrassonográfica da estimativa de peso fetal recorrendo apenas a parâmetros lineares (comprimento do fémur - FL - e espessura de tecido mole a meio da coxa fetal - STT), no período precedente ao parto.
\end{abstract}

received

July 27,2015

accepted

October 14, 2015
DOI http://dx.doi.org/

10.1055/s-0035-1570110. ISSN 0100-7203.
Copyright $(2016$ by Thieme Publicações License terms Ltda, Rio de Janeiro, Brazil
(๑) $\Theta \circledast$ 


\section{Palavras-chave}

- estimativa de peso fetal

- parto

- macrossomia

- recém-nascido de baixo peso
Métodos Realizamos um estudo prospectivo que incluiu gestações simples de termo, com feto cefálico, nas quais o parto ocorreu nas $48 \mathrm{~h}$ seguintes à avaliação ecográfica. A inclusão no estudo foi feita no momento de admissão ao bloco de partos para cesariana eletiva, indução do trabalho de parto ou trabalho de parto espontâneo. Foram excluídas todas as grávidas não caucasianas, com diagnóstico de diabetes gestacional ou evidência de rotura de membranas. A estimativa de peso fetal foi calculada através de uma fórmula previamente publicada [estimativa de peso fetal $=-1687,47+(54,1$ $\times \mathrm{FL})+(76,68 \times \mathrm{STT})$. A relação entre o peso real e o peso estimado foi analisada através da correlação de Pearson. O desempenho desta fórmula foi avaliado através do cálculo da percentagem de erro absoluto e não absoluto. Os recém-nascidos foram divididos em 3 grupos consoante o peso real: $<3000$ g; $3000 \mathrm{~g}-4000 \mathrm{~g} ; \mathrm{e}>4000 \mathrm{~g}$; para cada grupo foi calculada diferença média entre a estimativa de peso e o peso real e a percentagem de erro associada.

Resultados Incluímos 145 casos no estudo, cuja estimativa de peso e peso real se correlacionaram significativamente, apesar do valor de correlação ser pouco elevado $\left(p<0,001 ; R^{2}=0,197\right)$. Globalmente, a percentagem de erro absoluto foi $10,6 \%$. A percentagem de erro mais baixa correspondeu ao grupo com peso real entre $3000 \mathrm{~g} \mathrm{e}$ $4000 \mathrm{~g}$.

Conclusões Com este estudo demonstramos uma correlação fraca entre o peso real e a estimativa de peso fetal ultrassonográfica, quando calculada com base numa fórmula que usa o comprimento do fémur e a espessura de tecido mole a meio da coxa fetal, ambos parâmetros lineares. Ainda que a exclusão de parâmetros circunferenciais no cálculo da estimativa de peso fetal se venha a provar benéfica, esta não parece ser uma fórmula simultaneamente simples e precisa no cálculo da estimativa de peso fetal.

\section{Introduction}

The accurate prediction of estimated fetal weight (EFW) during labor could have a major impact on the appropriate obstetric management, especially in cases of suspected macrosomia or low birth weight. Macrosomic fetuses may lead to maternal and neonatal complications during labor, ${ }^{1-3}$ and low birth weight fetuses are at increased risk for perinatal morbidity and mortality. ${ }^{4}$ Thus, a good estimate of birth weight could contribute to the prevention of some of these complications. ${ }^{5,6}$

In clinical practice, the EFW established in the third trimester, usually around 30 weeks of gestation, is commonly used to predict the EFW at term. It admits the fetus has a constant growth. However, it is hardly the truth in all cases. $^{7,8}$ Additionally, previous studies have demonstrated that this third trimester fetal weight estimation does not allow us to identify the correct proportion of neither the small fetus at term nor the large ones, ${ }^{9,10}$ raising the need to evaluate fetal weight closer to birth.

Many equations are available for estimating fetal weight based on standard ultrasound fetal measurements and the most accurate include circumferential parameters, such as head circumference and abdominal circumference. ${ }^{7,11-13}$ Unfortunately, these parameters are more prone to intra and interobserver variability, ${ }^{11,12,14}$ especially at term, when these measurements are technically more difficult to obtain. During labor, aside the previously referred difficulties in performing an ultrasound and obtaining the correct measurements for the $\mathrm{EFW}$, it is necessary to perform this technique in a short period of time, giving the context of a labor ward.

A previously published study by Scioscia et a ${ }^{15}$ proposed a novel formula for EFW using the linear measurements of femur length (FL) and mid-thigh soft-tissue thickness (STT, involving adipose tissue plus lean mass). With this formula, the authors intended to obviate the imprecise and time consuming circumferential measurements, allowing it to be easily applied even during labor. Moreover, it includes a measurement of soft tissue, thought to be of great value to evaluate fetal growth deviations as it involves adipose tissue plus lean mass. ${ }^{15-19}$ Although previous studies have recently shown the benefits of these linear measurements, particularly mid-thigh STT, ${ }^{15,17-21}$ the advantage of this formula has yet to be established in order it can be routinely used, i.e. in the labor ward, where it could be most useful.

The aim of this study was to evaluate the accuracy of ultrasound fetal weight prediction during labor using a formula including only linear measurements, namely the FL and mid-thigh STT.

\section{Methods}

We conducted a prospective cohort study between July 2011 and August 2012 at the Department of Obstetrics and 
Gynecology of Santa Maria University Hospital, in Lisbon, after approval from the local ethics committee. We explained the study purpose and procedures to all enrolled women and a written informed consent was taken from each participant.

Inclusion criteria comprised pregnant women at term ( $\geq 37$ weeks of gestation), with singleton uncomplicated pregnancies; a fetus in cephalic presentation and who were likely to give birth within $48 \mathrm{~h}$. We included 155 patients admitted for elective cesarean section, induction of labor or spontaneous labor. As this formula for the EFW was tested only in Caucasian and in pregnancies with sonographic evidence of normal amniotic fluid, we excluded all nonCaucasian women and the ones with evidence of ruptured membranes. Also, we excluded all women with previously diagnosed gestational diabetes and the ones who gave birth beyond $48 \mathrm{~h}$ after enrollment. Gestational age was confirmed using recorded measurement of crown-rump length taken at 11-13 weeks' gestation.

During the admission to the labor ward, measurements of two fetal biometric parameters (FL and mid-thigh STT) were taken sonographically by one of three investigators (I.P., I.R., J.B.), all of them residents with obstetric ultrasound training, using an Aloka ProSound 2 (Aloka Co., Tokyo, Japan), an ultrasound machine equipped with a $3.5-6-\mathrm{MHz}$ convex transducer. When measuring the femur, concern was taken to obtain an optimal imaging by filling the entire screen with the bone and keeping its axis perpendicular to the probe. Femur length was obtained by placing the calipers at the junction of cartilage and bone, not including the epiphysis or the echogenic distal femoral point, since this is not a true anatomic structure. ${ }^{22}$ Using the same framed image, midthigh STT was measured linearly from the outer margin of the skin to the outer margin of the femur shaft. This measurement was taken in the middle third of the fetal thigh, providing that the greater and the lesser trochanters were turned upwards, to ensure the correct view of the lateral side of the femur (vastus lateralis, which is the largest part of the quadriceps femoris). ${ }^{15}$ For each parameter three measurements were obtained and recorded consecutively from three different frozen images. Actual birth weight was immediately measured after delivery by a neonatology nurse using a digital medical neonatal scale. At the time patients were included in the study, we also recorded demographic and clinical data, namely women's age and gestational age, height and weight before and at the term of pregnancy. After the measurements were done in all fetuses, we calculated the EFW using the previously published formula EFW= $-1687.47+(54.1 \times \mathrm{FL})+(76.68 \times \mathrm{STT})$, with EFW in $\mathrm{g}$ and FL and STT in mm (up to one decimal place), using the mean value of the three recorded measurements of FL and STT.

We calculated a sample size of 53 subjects to obtain a statistical power of $90 \%$ with $\alpha$ set at 0.01 and an expected coefficient of determination of 0.5 (as this seemed to possibly reveal a clinically relevant correlation).

The relationship between actual birth weight and EFW calculated with the novel formula was analyzed using Pearson's correlation. We assessed the performance of this for- mula by calculating the signed mean percent difference [(EFW - actual birth weight $) \times 100 /$ actual birth weight] and the absolute (unsigned) mean error [absolute (unsigned) difference between EFW and actual birth weight]. The mean weight difference and signed percentage error were calculated for birth weight divided into three subgroups: $<3000 \mathrm{~g}$; 3000-4000 g; and $>4000$ g. Descriptive parameters are expressed as mean and standard deviation (SD). Frequencies are presented as percentages. Sample size calculation and data analysis were performed using the Stata Statistical Software: Release 12 (StataCorp LP, Texas, USA) with significance set at $p<0.05$.

\section{Results}

Delivery within 48 h occurred in 155 cases, although only 145 cases were included in the analysis due to incomplete data. Maternal demographic and clinical characteristics are reported in -Table $\mathbf{1}$. Mean FL measurement was $71.0 \pm 3.3 \mathrm{~mm}$ and the mean mid-thigh STT was $13.9 \pm 3.2 \mathrm{~mm}$. Using the previously referred formula, the mean estimated fetal weight was $3217 \pm 344 \mathrm{~g}$ and ranged from $2441 \mathrm{~g}$ and $4314 \mathrm{~g}$. The mean birth weight was $3280 \pm 428 \mathrm{~g}$ and ranged from $2240 \mathrm{~g}$ and $4480 \mathrm{~g}$. We found a significant linear relationship between birth weight and EFW $\left(R^{2}=0.197, p<0.001\right)$ - - Fig. 1 .

The mean weight difference and mean percentage error were calculated by birth weight subgroups (-Table 2 ). The majority of subjects were comprised in the subgroup with birth weight between 3000 and $4000 \mathrm{~g}(n=106)$ and corresponded to the lowest mean percentage error $(0.3 \%)$. Concerning all subgroups, the absolute percent difference was $10.1 \pm 7.7 \%$, with a marked increase of error in the extreme ends of birth weight which tended to over- and underestimate fetal weight in small and large fetus, respectively. We verified a difference above $10 \%$ between birth weight and EFW in $40.7 \%$ of cases ( $n=59$ ), which is illustrated in - Fig. 2, although $76.6 \%$ of absolute error was ranging between 0 and $14.9 \%$.

\section{Discussion}

With this study, we intended to evaluate the clinical applicability of a novel formula in predicting birth weight in term pregnancies. The selected formula includes only two linear measurements (FL and mid-thigh STT), both performed in the femur, which is thought to improve fetal weight

Table 1 Demographic and clinical data

\begin{tabular}{|l|l|l|}
\hline Characteristic & Mean & SD \\
\hline Age (years) & 30.1 & 6.0 \\
\hline Gestational age (weeks) & 39.4 & 1.3 \\
\hline BMl $\left(\mathrm{kg} / \mathrm{m}^{2}\right)$ & 23.5 & 3.9 \\
\hline Weight gain $(\mathrm{kg})$ & 12.8 & 5.2 \\
\hline
\end{tabular}

Abbreviation: SD, standard deviation. 


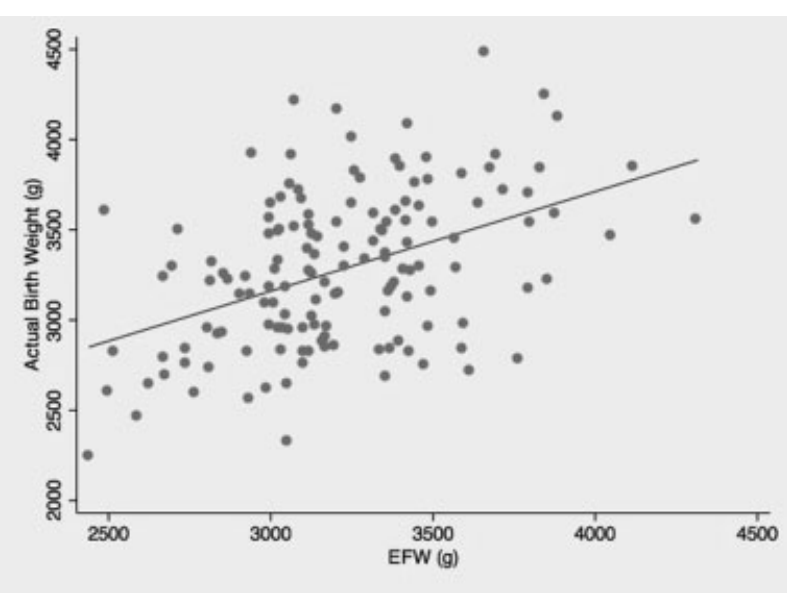

Fig. 1 Correlation between birth weight and EFW $\left(R^{2}=0.197\right.$, $p<0.001)$.

Table 2 Mean weight difference (EFW - actual birth weight) and mean percentage error ([EFW-actual birth weight] $\times 100 /$ actual birth weight) by actual birth weight group

\begin{tabular}{|l|l|l|}
\hline Birth weight & $\begin{array}{l}\text { Weight } \\
\text { difference } \\
(\mathrm{g}, \text { mean } \pm \text { SD) }\end{array}$ & $\begin{array}{l}\text { Signed \% difference } \\
\text { (mean } \pm \text { SD) }\end{array}$ \\
\hline $\begin{array}{l}<3000 \mathrm{~g} \\
(n=33)\end{array}$ & $301.1 \pm 275.8$ & $-6.2 \pm 10.5$ \\
\hline $\begin{array}{l}3000-4000 \mathrm{~g} \\
(n=106)\end{array}$ & $333.1 \pm 251.3$ & $0.3 \pm 12.7$ \\
\hline$>4000 \mathrm{~g}(n=6)$ & $540.3 \pm 245.4$ & $15.1 \pm 7.3$ \\
\hline
\end{tabular}

Abbreviation: SD, standard deviation.

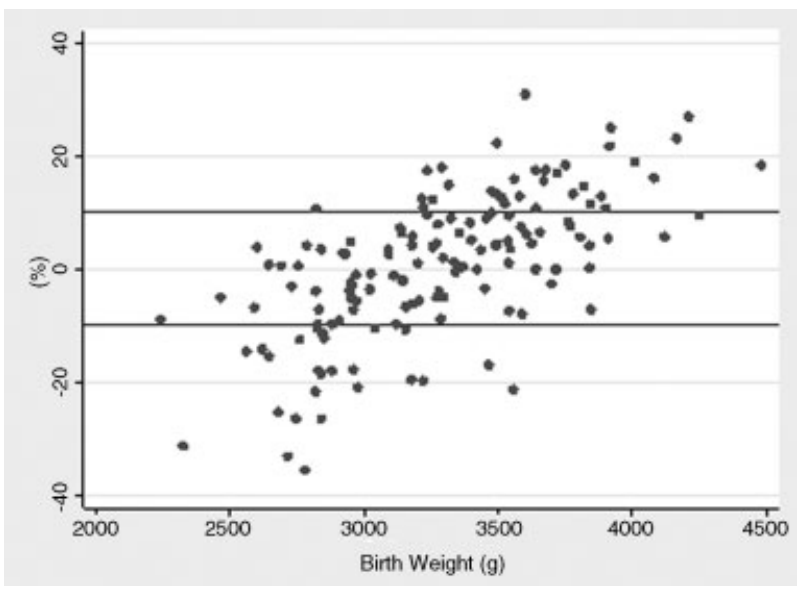

Fig. 2 Limits of agreement between actual birth weight and EFW (reference lines in -10 and $10 \%$ ).

estimation since it obviates the imprecise circumferential measurements of the head and abdomen. The head parameters do not consider the soft-tissue mass, which can lead to an underestimation of fetal weight. ${ }^{19}$ Additionally, these measurements may be more difficult to obtain at term, when the fetal head is engaged in the maternal pelvis. On the other hand, even though abdominal circumference is accepted as the most accurate parameter in determining fetal weight, it has also the difficulties inherent to a circumferential parameter, which can be enhanced if the ultrasound is performed during labor. ${ }^{7} 11-14$

Generally, we found a poor correlation between birth weight and EFW, yet statistically significant. Previously published studies reported higher correlations between estimated fetal weight and actual birth weight, namely Scioscia et $\mathrm{al}^{15}$ who tested the original formula in 69 women $\left(\mathrm{R}^{2}=0.68\right)$ and Abuelghar et al. ${ }^{17}$ who found a correlation of $\mathrm{R}^{2}=0.64$ in a group of 300 women, using the same formula. Our results contrast with the previously described since the correlation we found between estimated fetal weight and actual birth weight is not so evident. However, despite the poor correlation, the mean absolute error between birth weight and EFW (10.1\%) is in line with other findings, which set the acceptable error of a giving formula for calculating EFW around $10 \%{ }^{15,23-25}$ Still, mean absolute errors do not take into account under- or over-estimation biases and therefore mean signed percentage errors have been used in this study, the standard deviation of which also provides a measure of the random estimation error for the EFW.

Considering the subgroups of neonates with birth weight below $3000 \mathrm{~g}$ and above $4000 \mathrm{~g}$, even though these two groups comprise a substantially reduced number of subjects, we report a larger error between EFW and birth weight when compared with the neonates weighing between $3000 \mathrm{~g}$ and $4000 \mathrm{~g}$. Moreover, with this formula we tended to overestimate the weight of larger fetus and to underestimate the weight of the lighter ones, which was also previously noted with most formulas used to estimate fetal weight. ${ }^{26}$ Therefore, these estimates appear to be tending toward an 'average' birth weight fetus. As we stated before, our initial aim was to disclose the fetus at greater risk during labor, namely the macrosomic and with low birth weight, and that purpose we failed to achieve, also due to the reduced number of subjects at the extreme ends of birth weight, especially above 4000 g. Other authors ${ }^{3,27}$ suggest that a specific formula should be considered when fetal macrosomia is suspected to improve its recognition and, consequently, the management of this condition.

The limitations of our study must be considered. The unbalanced proportion of subjects in the subgroups of birth weight, especially the reduced number of macrosomic fetuses, weakens our results. Nevertheless, as stated before, our findings are in line with previous published studies despite we evaluated only six neonates with birth weight above $4000 \mathrm{~g}$. All the investigators who performed the ultrasound measurements were residents and all measurements were performed in the obstetrical emergency room, which may account for some inaccuracy related to the calculated EFW. Notwithstanding, it was our aim to evaluate the performance of this formula in the context of a labor ward, and, additionally, the performance of the residents in fetal weight estimation has already been evaluated previously with good results. ${ }^{25,28,29}$

The clinical importance of accurate fetal weight estimation at term is currently unquestionable. However, it is yet to 
be found a fetal weight estimation formula that it can be simultaneously accurate and simple, excluding time-consuming ultrasound parameters.

\section{References}

1 Najafian M, Cheraghi M. Occurrence of fetal macrosomia rate and its maternal and neonatal complications: a 5-year cohort study. ISRN Obstet Gynecol 2012;2012:353791

2 Weissmann-Brenner A, Simchen MJ, Zilberberg E, et al. Maternal and neonatal outcomes of macrosomic pregnancies. Med Sci Monit 2012;18(9):PH77-PH81

3 Bamberg C, Hinkson L, Henrich W. Prenatal detection and consequences of fetal macrosomia. Fetal Diagn Ther 2013;33(3): 143-148

4 Valero De Bernabé J, Soriano T, Albaladejo R, et al. Risk factors for low birth weight: a review. Eur J Obstet Gynecol Reprod Biol 2004; 116(1):3-15

5 Lindqvist PG, Molin J. Does antenatal identification of small-forgestational age fetuses significantly improve their outcome? Ultrasound Obstet Gynecol 2005;25(3):258-264

6 Walsh JM, McAuliffe FM. Prediction and prevention of the macrosomic fetus. Eur J Obstet Gynecol Reprod Biol 2012;162(2): $125-130$

7 Dudley NJ. A systematic review of the ultrasound estimation of fetal weight. Ultrasound Obstet Gynecol 2005;25(1):80-89

8 Faschingbauer F, Dammer U, Raabe E, et al. Sonographic weight estimation in fetal macrosomia: influence of the time interval between estimation and delivery. Arch Gynecol Obstet 2015; 292(1):59-67

9 Lalys L, Pineau JC, Guihard-Costa AM. Small and large foetuses: Identification and estimation of foetal weight at delivery from third-trimester ultrasound data. Early Hum Dev 2010;86(12): 753-757

10 Pressman EK, Bienstock JL, Blakemore KJ, Martin SA, Callan NA. Prediction of birth weight by ultrasound in the third trimester. Obstet Gynecol 2000;95(4):502-506

11 Kurmanavicius J, Burkhardt T, Wisser J, Huch R. Ultrasonographic fetal weight estimation: accuracy of formulas and accuracy of examiners by birth weight from 500 to 5000 g. J Perinat Med 2004;32(2):155-161

12 Shamley KT, Landon MB. Accuracy and modifying factors for ultrasonographic determination of fetal weight at term. Obstet Gynecol 1994;84(6):926-930

13 Yarkoni S, Reece EA, Wan M, Holford T, Romero R, Hobbins JC. Intrapartum fetal weight estimation: a comparison of three formulae. J Ultrasound Med 1986;5(12):707-710

14 Chang TC, Robson SC, Spencer JA, Gallivan S. Ultrasonic fetal weight estimation: analysis of inter- and intra-observer variability. J Clin Ultrasound 1993;21(8):515-519
15 Scioscia M, Scioscia F, Vimercati A, et al. Estimation of fetal weight by measurement of fetal thigh soft-tissue thickness in the late third trimester. Ultrasound Obstet Gynecol 2008;31(3):314-320

16 Yang F, Leung KY, Hou YW, Yuan Y, Tang MH. Birth-weight prediction using three-dimensional sonographic fractional thigh volume at term in a Chinese population. Ultrasound Obstet Gynecol 2011;38(4):425-433

17 Abuelghar W, Khairy A, El Bishry G, Ellaithy M, Abd-Elhamid T. Fetal mid-thigh soft-tissue thickness: a novel method for fetal weight estimation. Arch Gynecol Obstet 2014;290(6):1101-1108

18 Scioscia M, Stepniewska A, Trivella G, De Mitri P, Bettocchi S. Estimation of birthweight by measurement of fetal thigh softtissue thickness improves the detection of macrosomic fetuses. Acta Obstet Gynecol Scand 2014;93(12):1325-1328

19 Larciprete G, Di Pierro G, Barbati G, et al. Could birthweight prediction models be improved by adding fetal subcutaneous tissue thickness? J Obstet Gynaecol Res 2008;34(1):18-26

20 O'Connor C, Farah N, O'Higgins A, et al. Longitudinal measurement of fetal thigh soft tissue parameters and its role in the prediction of birth weight. Prenat Diagn 2013;33(10):945-951

21 Kalantari M, Negahdari A, Roknsharifi S, Qorbani M. A new formula for estimating fetal weight: The impression of biparietal diameter, abdominal circumference, mid-thigh soft tissue thickness and femoral length on birth weight. Iran J Reprod Med 2013; 11(11):933-938

22 Frates MC. Mistakes to avoid in the second and third trimesters: fetal measurements and anatomy. Ultrasound Clin 2012;7(1): $15-31$

23 Farah N, Stuart B, Donnelly V, Rafferty G, Turner M. What is the value of ultrasound soft tissue measurements in the prediction of abnormal fetal growth? J Obstet Gynaecol 2009;29(6): 457-463

24 Melamed N, Yogev Y, Meizner I, Mashiach R, Bardin R, BenHaroush A. Sonographic fetal weight estimation: which model should be used? J Ultrasound Med 2009;28(5):617-629

25 Predanic M, Cho A, Ingrid F, Pellettieri J. Ultrasonographic estimation of fetal weight: acquiring accuracy in residency. J Ultrasound Med 2002;21(5):495-500

26 Barel O, Vaknin Z, Tovbin J, Herman A, Maymon R. Assessment of the accuracy of multiple sonographic fetal weight estimation formulas: a 10-year experience from a single center. J Ultrasound Med 2013;32(5):815-823

27 Porter B, Neely C, Szychowski J, Owen J. Ultrasonographic fetal weight estimation: should macrosomia-specific formulas be utilized? Am J Perinatol 2015;32(10):968-972

28 Noumi G, Collado-Khoury F, Bombard A, Julliard K, Weiner Z. Clinical and sonographic estimation of fetal weight performed during labor by residents. Am J Obstet Gynecol 2005;192(5):1407-1409

29 Dimassi K, Douik F, Ajroudi M, Triki A, Gara MF. Ultrasound fetal weight estimation: how accurate are we now under emergency conditions? Ultrasound Med Biol 2015;41(10): $2562-2566$ 